\title{
Patterns of technological accumulation in European Union countries
}

\section{Introduction}

The importance of technological accumulation in manufacturing processes, technological advantage are a noticed issues in economic studies from the beginning of their development. At first, the contamination mechanism of industrial creativity was not noticed directly, its impact on the total productivity of production factors, usability, and the emerging economic value based on the process of knowledge accumulation. The second half of the twentieth century brings a deep reflection, mainly under the influence of dynamic structural changes in the global economy, on the possibilities of the description and inclusion of the issue of knowledge and its use in manufacturing processes to economic theory (Lucas, 1988, 1990; Romer, 1990; Grossman, Helpman, 1991; Mankiw et al., 1992; Barro and Sala-i-Martin, 1991, 2004).

An example of an R\&D product that is highly saturated in knowledge and having the potential for commercial exploitation is a new technology included in the patent description. In a legal sense, a patent is a right to the exclusive use of a new solution of a technical nature. This is considered to be one of the strongest intellectual property rights. In the scientific sense, it is the culmination of $R \& D$ activities. In economic terms, this is one of the stages of the innovation process. From the point of view of the person who is the owner, it is a resource and a potential market value. It has a relatively high ability to transform into a production factor. The properties of the patent description and exclusive rights (patent - understood in the strictest sense) cause that the patent information

\footnotetext{
* Jagiellonian University in Kraków, Faculty of Management and Social Communication, Institute of Economics, Finance and Management, e-mail: rafal.wisla@uj.edu.pl. The research results presented here were also published in: R. Wisła (2018), The Potential Technological Advantage of European Union Countries, Transylvanian Review, vol. XXVI, No. 30.
} 
constitutes a bridge between the results of the R\&D activities and their potential economic exploitation.

A patent is a collection of accumulated industrial knowledge that has the ability to influence the course of management processes. It is an economic category ascertained in both normative and positive economics. In the first case, it is considered on the level of institutional solutions (optimal patent policy, the effectiveness of patent systems, external effects); in the second case, it is considered as a measure of the dynamics and direction of changes in an economy.

It is a regularity that $R \& D$ activity and then patent and implementation activity are not symmetrically distributed within particular countries (or regional economies). Hence, the actual and important research issues are questions about (1) the reasons for the spatial differentiation of the effects of the innovation processes and policy, (2) adequate, national, and regional development strategy (specialization vs. diversification), or (3) the relationship between the 'success' nations and their neighbors (knowledge spillover effect vs. depletion effect).

This paper is an indirect response to the above-mentioned fundamental research questions. The scope of the research process presented in this paper is focused directly on the following issues: the structure of the distribution, directions, and dynamics of the developed technologies within the economies of the selected European Union countries, use of patent information to the patterns of technological accumulation, and a new approach to selecting and positioning smart specialization.

Techniques and production technology are micro-economic characteristics, and their transposition to the macro level raises many problems. Recognizing that technology means all processing of tangible and intangible assets into usable goods (in particular, that it constitutes an accumulated stream of scientific and technical knowledge on the practical use of the achievements of a specific area of science in industry, transport, medicine, etc.), its transposition and aggregation in macroeconomic terms will rely on the summing up of unit records of the rise of new scientific and technical knowledge within sectors, industries, or areas of technological development. It is assumed that individual records materialize the process of growing industrial knowledge and potential technological development. They lend themselves to quantification. The technological learning process favors the creation of technological potential, understood as a set of the technical and process solutions available to domestic businesses.

This terminological context leads to two main research goals; these are the identification of technological accumulation in selected European Union countries and the assessment of the differentiation of potential technological comparative advantages in the international system. In order to achieve the defined scientific objectives, the WIPO Technology Concordance Table and Balassa's Revealed Comparative Advantage (RCA) are used. 
The structure of the study is as follows. Section 2 discusses the literature in the field of technological accumulation. Section 3 describes the methodology and primary data used to achieve the goal of the study. Step 4 presents the results of the empirical analyses. The last section is a summary of the study.

\section{Literature review}

The accumulation of the capacities and capabilities of technological development embodied in title deeds for new technical solutions has been more dynamic in recent decades, with radical changes in the approaches and methods for carrying out manufacturing processes that are increasingly based on intangible resources. It should be clearly stated that, depending on the cultural or institutional circumstances, the accumulation process has a different course and different dynamics. "It seems justifiable to assume that the relationship between technological change and the cultural and institutional characteristics of a given nation is one of the most important causes of the observed differences in the rates of inventiveness and economic growth between countries" (Gomułka, 1998).

The economy is a complex adaptive system that changes over time. Hence, the need for a constant search for more-perfect research procedures relevant to a given stage of development (or, more specifically, methods for explaining these complexities as well as their causes and effects).

The research on the results from the relationship between scientific achievements, industrial developments, and structural changes in an economy initiated by J. Schumpeter (1934) emphasize particular skills and technological competence as a prerequisite towards obtaining comparative advantages (Malerba, Orsenigo, 1995). Compared with the traditional assumptions (R. Torrens, then D. Ricardo), the theory of comparative advantage should be now regarded as a logically cohesive structure of generalizations that explain the mechanism of the mutually beneficial exchange of goods under the conditions of diversified costs and applicability of specific technologies for the production of a given good (or bundle of goods).

In the original version, the leads in an industry, sector, or national economy stem from the relative abundance of certain types of resources and their use in the (spatial) distribution process of labor. In 1776, A. Smith introduced the concept of absolute advantages, which are based on specialized production resulting in advantages in terms of cost and performance. In 1817, D. Ricardo argued that an absolute difference in production costs is not necessary for the exchange to be profitable. Cost differences and comparative advantages create the directions of trade flows. It is ultimately the level of the relative alternative cost of production of a given good that can determine the benefits of the exchange. It should be emphasized that differences in the relative costs of production (which are vital 
to the development of exchange) are the result of the differences in the level of technology used in production, productivity, and wages. D. Ricardo's theory is a useful economic model to this day, although S. Golub and Ch. Hsieh (2000) indicate that, "despite its large educational usefulness, in recent decades the model has been ignored in the professional literature," mainly because of its initially adopted assumptions. They indicated the 1960s, when the model was extensively used in economic studies (Stern, 1962; Balassa, 1963, 1965). Since the beginning of the 21st century, a renaissance of empirical research on comparative advantages has been observed (Eaton, Kortum, 2002; Kerr, 2009; Chor, 2010; Levchenko, Zhang, 2012).

The index first proposed by Balassa (1965) - the index of revealed comparative advantage (RCA) - was widely used (along with its further modifications). According to Balassa, this index discloses a comparative advantage - if the share of exports of the $j$-th sector in the $i$-th country in the total exports of the country is higher than the share of this sector in the global structure of exports, it is indirect evidence of a comparative advantage in terms of the products of the $j$-th sector in this country with respect to a specific group of countries. It should be noted that the changes in the index result not only from differences in productivity but also in changes caused by the policy of export stimulation, so care should be exercised in interpreting the results. Costinot et al. (2012) and, further, Leromain, Orefice (2013) emphasize the importance of differences in access and use of technology as determinants of diversification in patterns of trade. They have also drawn attention to such factors as geographical distance, colonial trade/legacy, language, etc. as other important determinants in measuring comparative advantages.

This study uses the concept of comparative advantage, giving it a slightly different meaning and interpretation. Balassa's RCA index is used to measure the potential sources of advantage; i.e., those technological resources not fully disclosed and used in the national context. These resources are the hard-toquantify results of the activities of human capital in the form of new scientific and technical knowledge that, analyzed from a technological perspective, allow us to determine the potentials of national economies (R\&D competences, continuity in the development of a specific field of technology, and the ability to network) or the lack thereof.

\section{Research design}

The concepts of sectors and areas of technological development describe different aspects of the production process. They should be analyzed separately. 
The classifications of technologies and areas of technological development have been created and developed by many institutions. While creating technological taxonomies is not an impossible task (although it naturally raises substantive disputes), the measurement itself of this process is a major challenge in the process of scientific knowledge. This is particularly difficult from the macroeconomic perspective. Starting with the general assumption that the description of a new technical solution is part of the process of technological development, concordance tables are created that link sectoral classifications to the International Patent Classification (IPC) - a hierarchical system for classifying inventions. An important contribution in creating the concordance tables was introduced by Schmoch (2008), whose table became the basis for creating the concordance table of the World Intellectual Property Organization. This has been used in achieving the research objectives in this article. The appendix shows the classification of the areas of technological development using the schema.

Creating technological fields using the IPC schema should be assessed as a valuable way of addressing the problems in measuring the direction and dynamics of changes in technological developments in each layer of an economic analysis. The defects in patent metadata are compensated for by the possibility of working with full collections, often reaching hundreds of thousands of items (when they are considered for national economies).

Using the idea of group indexes for Balassa's relative sizes $(1963,1965)$, which are used in international comparisons by Eaton, Kortum (2002); Nesta, Patel (2005); Kerr (2009); Chor (2010); Levchenko, Zhang (2012); below, these are given the following meaning:

$$
\operatorname{RPTA}_{i k}=\left(\frac{P_{i k}}{\sum_{k} P_{i k}}\right) /\left(\frac{\sum_{i} P_{i k}}{\sum_{i k} P_{i k}}\right)
$$

where:

$R P T A_{i k}$ - the relative potential technological advantages of the $i$-th country using the concordance table (see appendix) connecting the areas of technology and international patent classification, we can give the following meanings for the individual parameters:

$P_{i k}$ - the number of technical solutions of the $i$-th country in the area of the $k$-th technology,

$\Sigma_{k} P_{i k}-$ the total number of technical solutions of the $i$-th country in all of the technological areas considered,

$\sum_{i} P_{i k}-$ the total number of technical solutions within the $k$-th technology of all of the $i$-th countries studied,

$\sum_{i k} P_{i k}-$ the total number of technical innovations in all technology areas of all of the countries studied (each within the defined analytical groups). 
The index value belongs to set RPTA $\in(0,+\infty)$. A value above unity indicates the relative technological advantage within the surveyed population (e.g., the specific set of European countries). A value below unity indicates a relatively weak competitive position in a particular field of technology against others. When we perform the simple modifications of $($ RPTA -1$) /($ RPTA +1$)=$ RPTA $^{*}$, then RPTA $^{*} \in[-1 ;+1]$. RPTA is the result of two factors: the dynamics of the relative partial sizes and the changes in the structure of these factors.

While seeking patent protection, the entity chooses the procedure based on which of the proceedings will take place. These procedures can be divided into national, regional, and international. The procedure of European patent application was selected to implement and achieve the defined research goal.

The collection of patent metadata for the countries covered by the research was extracted directly from the patent information database of the European Patent Office in June 2015. The total number of patents granted during the accepted research period for the selected countries is 686,052 .

The years of 2000-2014 are accepted as the research period. The following two considerations were crucial in choosing the research period: first, the availability and completeness of patent data in the EPO mode; and second, the period of 15 years is long enough to capture the processes of technological accumulation.

\section{Results}

Using the ratio of the absolute measure of dispersion - the standard deviation $(\sigma)$ and the mean value $(\mu)$ - we obtain the classic coefficient of variation $\left(V_{i}\right)$, which determines the degree of diversification of the technological specialization in the time and space studied. The higher the dispersion, the narrower the technological specialization of the country. Low values of this characteristic can be interpreted as a relatively equally spread technological competence throughout the population of the considered areas of technological development. In examining the abovementioned relationship from a technological perspective, we can identify the relative technological advantage of a country and give an indication of its diversity within the group. A higher variability index value indicates an emerging technological specialization; a lower weakly exploited area, or one exploited by all countries within a similar range and with similar search results. The group subjected to analysis are the European countries before EU expansion in 2004 (hereafter referred to below as the EU15). 


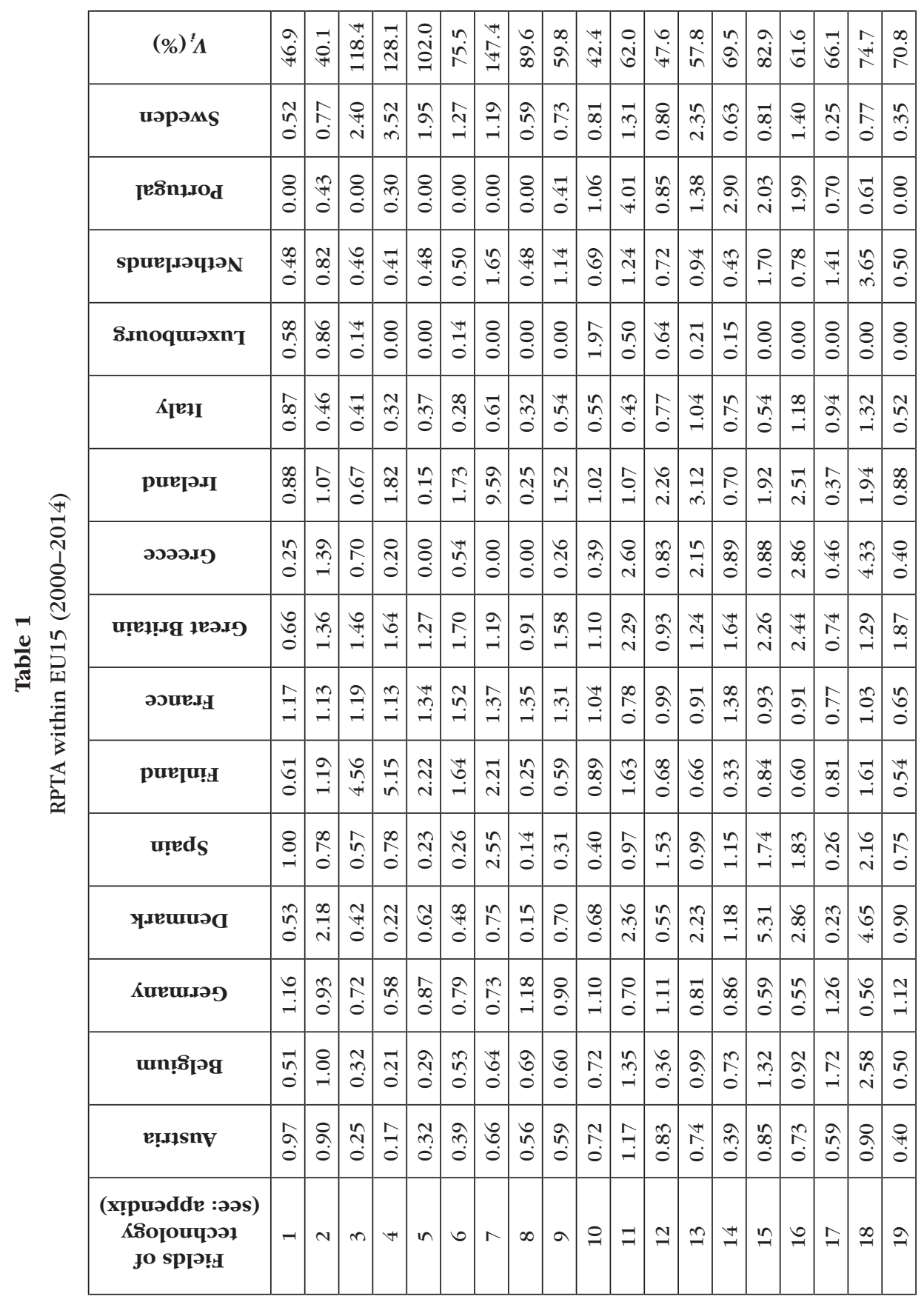




\begin{tabular}{|c|c|c|c|c|c|c|c|c|c|c|c|c|c|c|c|c|c|c|c|c|}
\hline$(\%)^{t} \Lambda$ & 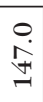 & $\begin{array}{l}\infty \\
\dot{0} \\
i\end{array}$ & $\begin{array}{l}+1 \\
\dot{0} \\
\tilde{n}\end{array}$ & $\overrightarrow{\mathrm{v}}$ & $\vec{f}$ & 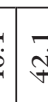 & jo & $\begin{array}{c}0 \\
\infty \\
\infty \\
+\end{array}$ & $\begin{array}{l}n \\
i n \\
i\end{array}$ & $\vec{\infty}$ & $\stackrel{0}{i}$ & : & $\begin{array}{l}\stackrel{\sim}{*} \\
\stackrel{f}{*}\end{array}$ & $\hat{\vartheta}$ & $\begin{array}{l}n \\
\infty \\
i\end{array}$ & & & 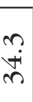 & & \\
\hline иәрәмя & 先 & के & $\mid \begin{array}{l}\infty \\
0 \\
0 \\
\dot{0}\end{array}$ & $\begin{array}{c}\infty \\
\infty \\
0\end{array}$ & $\stackrel{n}{-}$ & $\approx$ & 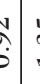 & $\stackrel{n}{n}$ & $\hat{\imath}$ & $\hat{\sigma}$ & $\begin{array}{l}0 \\
\stackrel{0}{0}\end{array}$ & $\stackrel{\leftrightarrow}{\stackrel{\rho}{\rho}}$ & oे & $\stackrel{+}{\stackrel{+}{0}}$ & $\infty$ & & & $\begin{array}{l}\circ \\
\infty \\
0\end{array}$ & $\underset{7}{7}$ & $\hat{8}$ \\
\hline 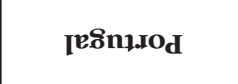 & $\begin{array}{l}\hat{6} \\
0\end{array}$ & $\stackrel{?}{\stackrel{f}{0}}$ & $\begin{array}{l}8 \\
\dot{0} \\
\dot{0}\end{array}$ & $\stackrel{\infty}{\stackrel{\Omega}{\sim}}$ & $\begin{array}{l}\infty \\
\infty \\
0\end{array}$ & 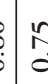 & $\stackrel{1}{\circ}$, & 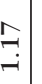 & $\stackrel{\leftrightarrow}{\stackrel{\theta}{-}}$ & $\begin{array}{l}1 \\
\infty \\
0\end{array}$ & $\underset{-1}{\sigma}$ & $\stackrel{\wp}{\circ}$ & $\stackrel{\infty}{\stackrel{0}{0}}$ & 常 & in & & & & $\approx$ & ఫே \\
\hline sрuе[.Іәч] & $\begin{array}{l}\text { : } \\
0\end{array}$ & $\begin{array}{l}\stackrel{n}{\hat{0}} \\
\dot{0}\end{array}$ & $\begin{array}{l}8 \\
8 \\
\dot{0}\end{array}$ & $\stackrel{?}{=}$ & $\stackrel{-}{=}$ & $\stackrel{N}{2}$ & $\begin{array}{lll}\mathrm{v} & 1 \\
\mathrm{i} & \end{array}$ & $\begin{array}{r}n \\
\tilde{n} \\
0\end{array}$ & $\tilde{r}$ & $\stackrel{\circ}{\circ}$ & $\begin{array}{l}\vec{F} \\
\dot{r}\end{array}$ & $\stackrel{\Im}{ت}$ & $\begin{array}{l}\infty \\
\infty \\
\infty \\
0\end{array}$ & $\stackrel{+}{\stackrel{+}{0}}$ & $\hat{0}$ & & & $\stackrel{\sim}{\stackrel{H}{-}}$ & $\approx$ & $\underset{+}{\stackrel{0}{r}}$ \\
\hline 8.snoquəxnT & $\begin{array}{l}\stackrel{\infty}{\circ} \\
=\end{array}$ & $\begin{array}{l}\infty \\
\infty \\
0\end{array}$ & $\begin{array}{l}\dot{8} \\
\dot{0} \\
\dot{0}\end{array}$ & $\mid \begin{array}{l}\mathcal{N} \\
0 \\
0\end{array}$ & $\mid \begin{array}{c}\vec{N} \\
\mathrm{~N}\end{array}$ & 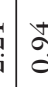 & bे & 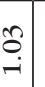 & $\stackrel{n}{\stackrel{n}{-}}$ & กี & $\begin{array}{l}+1 \\
0 \\
0\end{array}$ & $\underset{\forall}{\stackrel{\infty}{\stackrel{\infty}{*}}}$ & $\underset{+}{F}$ & $\stackrel{8}{8}$ & $\stackrel{\unlhd}{\stackrel{J}{~}}$ & & & $\stackrel{\infty}{\stackrel{2}{\sim}}$ & $a$ & $\begin{array}{l}\vec{\infty} \\
\stackrel{\infty}{\sigma}\end{array}$ \\
\hline $\boldsymbol{K}_{[} \boldsymbol{E}_{\mathbf{1}}$ & $\begin{array}{l}\infty \\
\infty \\
0\end{array}$ & $\stackrel{9}{0}$ & $\begin{array}{l}\tilde{S} \\
0 \\
0\end{array}$ & & $\begin{array}{l}0 \\
1 \\
0\end{array}$ & 8 & S. & Pج & $\begin{array}{l}1 \\
\infty \\
0 \\
0\end{array}$ & $\stackrel{\text { N }}{\sim}$ & $\stackrel{n}{n}$ & $\stackrel{\infty}{\sim}$ & $\hat{\sigma}$ & $\stackrel{\infty}{\circ}$ & $\stackrel{\circ}{\infty}$ & & $\begin{array}{l}0 \\
\dot{v} \\
\end{array}$ & $\stackrel{\rightarrow}{\rightrightarrows}$ & $=$ & $\stackrel{\circ}{\stackrel{0}{n}}$ \\
\hline рuе[ə.गI & 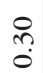 & ڤిరి & \begin{tabular}{l}
8 \\
\hdashline \\
0
\end{tabular} & $\stackrel{\circ}{\circ}$ & $\begin{array}{c}\infty \\
1 \\
0\end{array}$ & $l_{0}^{+}$ & 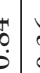 & 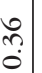 & 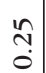 & $\frac{1}{0}$ & $\stackrel{\substack{\sim \\
\sim}}{ }$ & $\begin{array}{l}\infty \\
\infty \\
0\end{array}$ & $\stackrel{\overbrace{}}{\tilde{0}}$ & $\stackrel{+}{n}$ & n & & & $\stackrel{N}{\sim}$ & 우 & $\begin{array}{l}\text { ○. } \\
\text { I }\end{array}$ \\
\hline әววว.У & $\begin{array}{l}\infty \\
0 \\
0\end{array}$ & $\begin{array}{l}+ \\
\infty \\
0\end{array}$ & $\begin{array}{l}n \\
\infty \\
0 \\
0\end{array}$ & $\stackrel{\infty}{n}$ & $\underset{\sim}{\tilde{n}}$ & 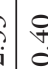 & $\begin{array}{l}0 \\
+1\end{array}$ & $\begin{array}{l}\infty \\
0 \\
\dot{\mathrm{j}}\end{array}$ & $\overrightarrow{\mathrm{N}}$ & $\begin{array}{l}\stackrel{2}{n} \\
\stackrel{0}{0}\end{array}$ & $\stackrel{n}{\sim}$ & $\stackrel{n}{r}$ & $\stackrel{\infty}{\stackrel{\infty}{n}}$ & $\stackrel{t}{\stackrel{t}{0}}$ & $\stackrel{n}{n}$ & & C. & $\widehat{్}$ & $\approx$ & $\stackrel{\sim}{\exists}$ \\
\hline u!๒џ!. & $\infty$ & $\stackrel{\infty}{1}$ & 8 & के & 2 & $\frac{1}{n}$ & & 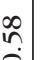 & oे & $\stackrel{0}{2}$ & 6 & $\stackrel{\infty}{+}$ & 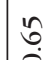 & in & $\infty$ & & 6 & $\infty$ & 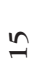 & $\stackrel{-1}{\pi}$ \\
\hline әЈUе..H & $\exists$ & $\begin{array}{l}\infty \\
\infty \\
0\end{array}$ & 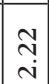 & $\hat{a}$ & ô & 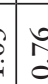 & $\begin{array}{l}2 \\
\dot{0}\end{array}$ & $\begin{array}{l}\vec{b} \\
0 \\
0\end{array}$ & $\stackrel{+}{a}$ & $\begin{array}{l}n \\
n \\
0\end{array}$ & $\tilde{\sigma}$ & $\begin{array}{l}\infty \\
\infty \\
0\end{array}$ & $\stackrel{\infty}{\circ}$ & $\stackrel{\sim}{\sim}$ & $\bar{a}$ & & 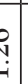 & $\begin{array}{l}\infty \\
\infty \\
\infty \\
0\end{array}$ & $\stackrel{\infty}{\sim}$ & $\overrightarrow{\hat{v}}$ \\
\hline рue[u! & $\overline{\hat{o}}$ & $\hat{\sigma}$ & $\begin{array}{l}0 \\
n \\
0\end{array}$ & $\stackrel{1}{0}$ & $\stackrel{\text { ñ }}{\text { r }}$ & in & 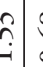 & 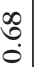 & $\stackrel{\text { ff }}{0}$ & $\begin{array}{l}\stackrel{\partial}{\alpha} \\
\text { id }\end{array}$ & $\begin{array}{l}1 \\
\infty \\
0\end{array}$ & $\stackrel{\sim}{\sim}$ & $\stackrel{\infty}{\sim}$ & సิ & ¿̊ & & $?$ & $\begin{array}{l}\stackrel{0}{\infty} \\
0 \\
0\end{array}$ & $\approx$ & $\stackrel{+}{a}$ \\
\hline u!eds & \begin{tabular}{l}
$\stackrel{0}{\infty}$ \\
\hdashline \\
0
\end{tabular} & $\begin{array}{l}\hat{N} \\
0\end{array}$ & $\mid \begin{array}{l}+1 \\
n \\
0\end{array}$ & $\stackrel{\infty}{0}$ & $\stackrel{\overbrace{}}{0}$ & $\stackrel{8}{8}$ & $\mid$ & $\begin{array}{c}\infty \\
\infty \\
0\end{array}$ & $\stackrel{\text { f }}{0}$ & $\begin{array}{ll}10 \\
0\end{array}$ & $\underset{r}{2}$ & 곡 & : & $\underset{\sim}{8}$ & $\stackrel{T}{\sigma}$ & & مُ & & $\approx$ & $\begin{array}{l}\text { ○े } \\
\text { in }\end{array}$ \\
\hline ૧лешиว & $\begin{array}{l}\hat{1} \\
0 \\
0\end{array}$ & $\stackrel{t}{\stackrel{t}{0}}$ & $\mid \begin{array}{l}0 \\
+1 \\
0\end{array}$ & ت. & $\stackrel{I}{=}$ & $\infty$ & \begin{tabular}{l|l}
0 \\
$\stackrel{0}{0}$
\end{tabular} & $\stackrel{t}{t}$ & $\stackrel{+}{a}$ & $\underset{+}{\stackrel{f}{0}}$ & $\stackrel{\Perp}{\leftrightarrows}$ & 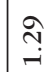 & $\begin{array}{l}8 \\
0 \\
0\end{array}$ & $\stackrel{\tilde{N}}{0}$ & " & & 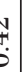 & $\stackrel{\overbrace{}}{\stackrel{\overbrace{}}{~}}$ & $\approx$ & $\stackrel{\infty}{\stackrel{0}{8}}$ \\
\hline Киеய.эว & 2 & $\stackrel{\infty}{=}$ & $\tilde{\varrho}$ & $\hat{n}$ & $\underset{\sim}{+}$ & $\tilde{a}$ & $\overbrace{}^{n}$ & $\stackrel{\infty}{\underset{-}{\sim}}$ & $\stackrel{\sim}{\sim}$ & $\stackrel{\sim}{\sim}$ & $\stackrel{n}{\hat{\sigma}}$ & : & $\stackrel{\unlhd}{\stackrel{\sim}{\sim}}$ & $\stackrel{\sim}{\rightleftharpoons}$ & 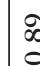 & & $\begin{array}{l}0 \\
0 \\
\\
\end{array}$ & $\hat{a}$ & 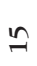 & $\stackrel{+}{\vec{N}}$ \\
\hline 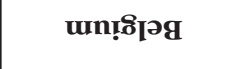 & $\widehat{\hat{i}}$ & - & $\stackrel{8}{0}$ & $\stackrel{n}{n}$ & $\underset{-}{\mathbb{*}}$ & $\begin{array}{l}4 \\
\vdots \\
0\end{array}$ & 定 & $\begin{array}{c}-1 \\
0 \\
0\end{array}$ & $\begin{array}{l}\mathbb{J} \\
0 \\
0\end{array}$ & $\begin{array}{l}0 \\
\text { nn }\end{array}$ & $\stackrel{\text { fn }}{-}$ & 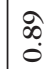 & 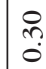 & $\stackrel{\overbrace{}}{\stackrel{2}{0}}$ & ๕ & & 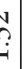 & $\stackrel{\infty}{\underset{i}{i}}$ & $\Xi$ & $\hat{N}$ \\
\hline e!!nsny & $\underset{i}{\hat{N}}$ & $\hat{\sigma}$ & 8 & $\tilde{\sigma}$ & $\stackrel{1}{=}$ & 8 & B. & $\underset{r}{\stackrel{R}{r}}$ & 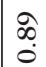 & - & $\exists$ & 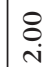 & $\bar{\sigma}$ & $\stackrel{\infty}{\infty}$ & ஓ & & f. & $\begin{array}{l}\stackrel{1}{N} \\
\stackrel{i}{N}\end{array}$ & 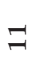 & $\underset{\sigma}{\infty}$ \\
\hline 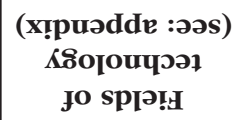 & ำ & $\vec{v}$ & กิ & $\approx$ & $\stackrel{4}{d}$ & $\stackrel{n}{2}$ & & $\stackrel{৩}{\sim}$ & ก & $\stackrel{\infty}{\sim}$ & ฟิ & in & $\bar{n}$ & กี & $\tilde{n}$ & & & $n$ & $\begin{array}{l}\vec{\Lambda} \\
\vec{a}\end{array}$ & @) \\
\hline
\end{tabular}


Table 1 shows the cumulative RPTA values from the period of 2000-2014 obtained using the patent metadata set of the European Patent Office (EPO) and the technology concordance table (see appendix). From Table 1, the following findings can be concluded for the EU15 group:

1) the RPTA index value above unity indicates a potential technological advantage within the surveyed population (EU-15); considering this criterion, the following leaders should be indicated (i.e., the countries with the highest number of potentially competing technologies); these are France (with 18 potential relative technology advantages) ${ }^{1}$, Ireland ${ }^{2}$ (16), Germany ${ }^{3}$, United Kingdom $^{4}$ (15), and further Belgium, Denmark, Spain, Finland, Greece, Portugal, the Netherlands (13), and then Sweden (12), Austria, Italy (11), and Luxembourg (9);

2) the highest technological concentration is observed in microstructural and nanotechnology technologies (attention here to Greece and France); it is also relatively high in terms of management IT systems (Ireland), plastics and metallurgy (Luxembourg, Belgium, Austria), and digital communications and telecommunications (in both cases, the decisive leader is Finland);

3 ) the most exploited fields of technological development simultaneously in all of the countries surveyed are chemical engineering, civil engineering, and processing and surface-coating technologies;

4) the biggest European economies (Germany, France, United Kingdom) have a relatively balanced development in all 35 analyzed technological fields;

5 ) in the case of small economies within the EU15 study group (Luxembourg, Greece, and Ireland), the greatest relative technological specialization can be observed.

Table 2 contains the groups of quartile technological development fields (potential advantages) at three time points during the period studied (i.e., 2000, 2008, and 2014). The first quartile group includes the countries with the highest number of technological fields in which they have the potential technology advantages; the last (fourth) quartile group includes countries with the lowest values of the characteristic.

\footnotetext{
1 If we take into account the proximity and increased tolerance in a range of [0.9:1.10] in the case of four fields of technology, a moderately successful advance should be noted in the 18 chosen fields of technology (i.e., the value of the indicator is slightly greater than 1) and omission in the case of 7 fields of technology (i.e., the value of the indicator is slightly lower than 1).

2 Moderate success in advance - in the case of four fields of technology, and without omissions.

3 Moderate success in advance - in the case of four fields of technology, and apart from six fields.

4 Moderate success in advance - in the case of one technological field, and apart from two fields.
} 
Table 2

Quartile groups of fields of technological development during period of 2000-2014 (EU15)

\begin{tabular}{|l|l|l|l|}
\hline \multirow{2}{*}{$\begin{array}{c}\text { Quartile } \\
\text { group }\end{array}$} & \multicolumn{1}{|c|}{2000} & \multicolumn{1}{c|}{2008} & \multicolumn{1}{c|}{2014} \\
\cline { 2 - 4 } First & $\begin{array}{l}\text { Germany, France, Unit- } \\
\text { ed Kingdom, Sweden }\end{array}$ & $\begin{array}{l}\text { France, UK, Germany, } \\
\text { Spain }\end{array}$ & $\begin{array}{l}\text { France, Germany, Spain, } \\
\text { UK }\end{array}$ \\
\hline Second & $\begin{array}{l}\text { Belgium, Denmark, } \\
\text { Spain, Finland }\end{array}$ & $\begin{array}{l}\text { Sweden, Denmark, } \\
\text { Italy, Belgium }\end{array}$ & $\begin{array}{l}\text { Ireland, Belgium, Portu- } \\
\text { gal, Italy }\end{array}$ \\
\hline Third & $\begin{array}{l}\text { Ireland, Italy, the Neth- } \\
\text { erlands, Austria }\end{array}$ & $\begin{array}{l}\text { Ireland, the Nether- } \\
\text { lands, Finland, Greece }\end{array}$ & $\begin{array}{l}\text { The Netherlands, Fin- } \\
\text { land, Denmark, Austria }\end{array}$ \\
\hline Fourth & $\begin{array}{l}\text { Luxembourg, Greece, } \\
\text { Portugal }\end{array}$ & $\begin{array}{l}\text { Luxembourg, Austria, } \\
\text { Portugal }\end{array}$ & $\begin{array}{l}\text { Sweden, Greece, Luxem- } \\
\text { bourg }\end{array}$ \\
\hline
\end{tabular}

Source: own study

From Table 2, the following general findings can be concluded: (1) at the three time points investigated, the first quartile group included France, the UK, and Germany; (2) Luxembourg was consistently placed in the last quartile group; (3) in the case of the other countries, there is a relatively high volatility of places occupied in the quartile ranking.

An analysis of the correlation using Spearman's rank correlation coefficient among the EU15 during years $t$ and $t-1$ shows a fading correlation during the period analyzed (Fig. 1):

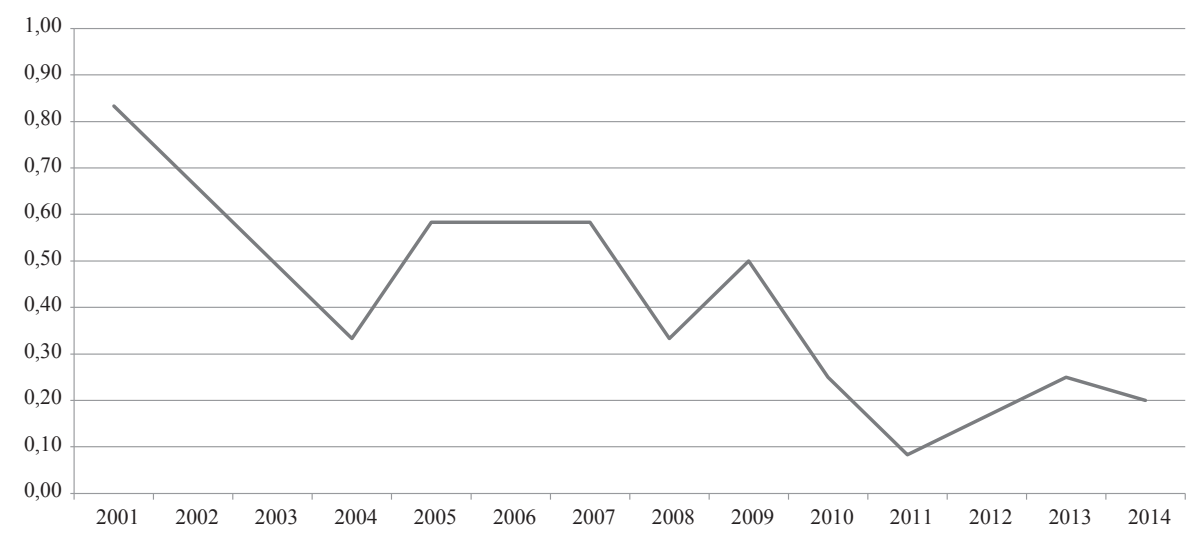

Fig. 1. Values of Spearman rank correlation coefficient among EU15 countries Source: own study 
Further, using (a) the coefficient of variation based on the standard deviation (i.e., the quotient of standard deviation and the unweighted arithmetic mean $-V_{s}$ ), (b) the coefficient of variation based on the average deviation (i.e., the ratio of the average deviation to the unweighted arithmetic mean $-V_{d}$ ), (c) the coefficient of variation based on the deviation quartile (i.e., the ratio of quartile deviation and median $\left.-V_{Q}\right)$, and considering that the coefficients of variation used $\left(V_{s}, V_{d}, V_{Q}\right)$ are a mapping of $\sigma$-convergence of the issue under examination, it cannot be said that the countries in the EU15 group have clearly assimilated to the extent of their number of developed fields of technology (see Fig. 2).

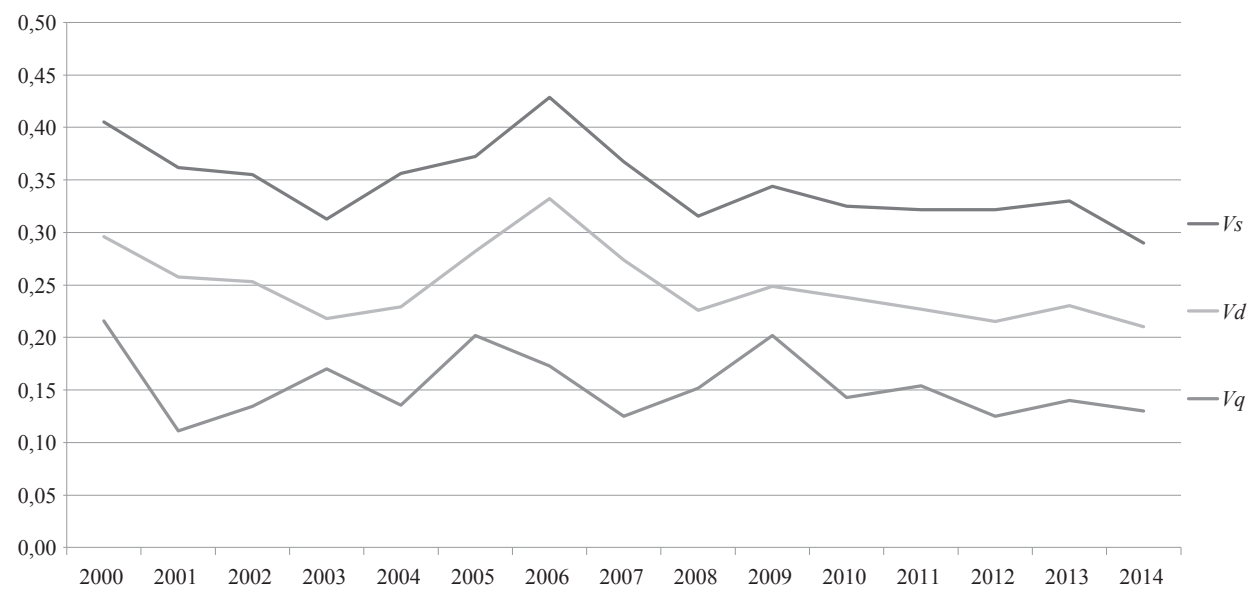

Fig. 2. Coefficients of variation in developed technological fields during period of 2000-2014

Source: own study

The variation in the number of developed fields of technology is generally determined by the size of the economy. For smaller economies, an important role is played by foreign capital, which promotes technological diversification in the country (as is the case in Ireland).

The above analysis is further enriched by a cluster analysis (Everitt et al. 2011; Kaufman, Rousseeuw 2005).

On the basis of these calculations, dendrograms for each technological process pair within groups of countries were created. These represent the division into clusters (groups) of countries resulting from the Euclidean distances between the standardized values of attributes and the arithmetic average distance between the clusters. 


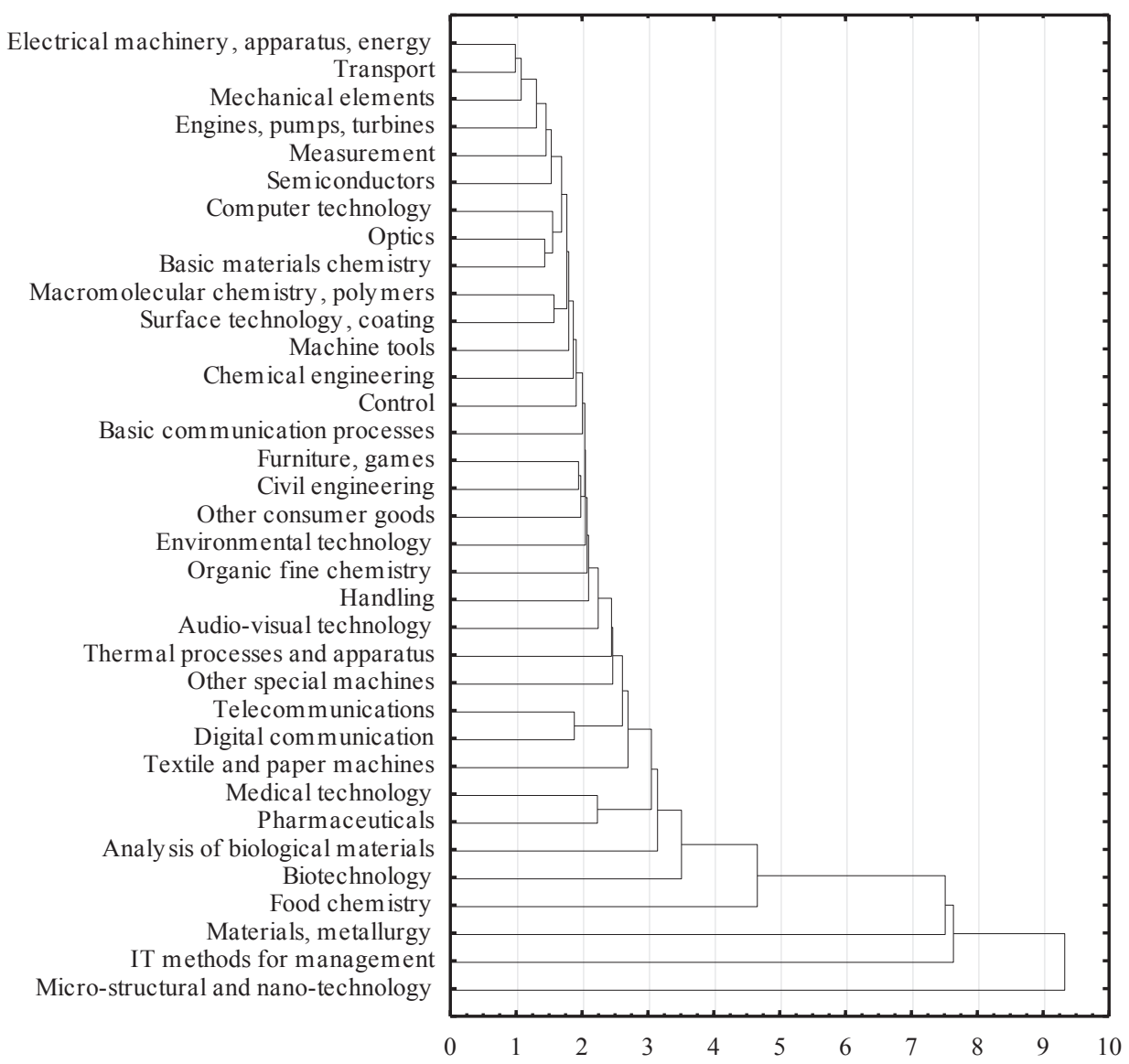

Fig. 3. Dendrogram of technological clusters in EU15

Source: own study

In order to isolate the clusters of the potential technology advantages that were most similar to each other, a critical distance of 4 was taken into account.

Reading Figure 3 leads to the deletion of a de facto two-part structure of technological groups in the EU15 (for which the degree of linking among the countries in terms of the various technologies is greatest): the first (covering 31 technological fields) developed relatively evenly; the second (distinctly different from the first) includes the following technologies in the field: food chemistry, materials and metallurgy, IT methods for management, and microstructural technology and nanotechnology. 


\section{Conclusions}

Innovation research does not provide direct knowledge of technological accumulation and technological changes. Patent information provides greater opportunities in this field. It goes deeper into those processes compared to other alternative methodological approaches. Its main advantage is the high flexibility of aggregation and disaggregation of the processes analyzed. This allows for the identification of a strategy for the directions of future development. Patent information and innovation surveys provide the most important knowledge on the trends and dynamics of technological change at the micro-, meso-, and macro-economic levels.

The analysis of the potential comparative technological advantages in two groups of countries with distinctly different levels of development using a single methodological approach for achieving the purpose of this study enables us to derive the following general conclusions:

1) the level of development determines the number of developed specializations; the largest economies are characterized by the greatest diversity of potential technological advantages, and the smallest economies are characterized by the highest specialization;

2) a quartile analysis shows high stability among the technology leaders during the period analyzed and high variability within the second and third groups, which is further confirmed by the course of the coefficient of variation based on the quartile deviation;

3 ) in the areas of microstructural technology and nanotechnology, the largest concentration is observed;

4) relatively evenly exploited fields of technological development in the EU15 are chemical engineering, civil engineering, and processing and surface-coating technologies.

\section{References}

Balassa, B. (1965) 'Trade Liberalisation and "Revealed" Comparative Advantage', The Manchester School, vol. 33(2), pp. 99-123.

Balassa, B. (1963) 'An Empirical Demonstration of Classical Comparative Cost Theory', The Review of Economics and Statistics, vol. 45(3), pp. 231-238.

Barro, R. and Sala-i-Martin, X. (2004) Economic growth. Boston MA: MIT Press. Barro R. and Sala-i-Martin X. (1991) 'Convergence Across States and Regions', Brookings Papers on Economic Activity, No. 1/1991, pp. 107-182.

Basberg, B. (1982) 'Technological change in the Norwegian whaling industry: A case study of the use of patents-statistics as a technology indicator', Research Policy, vol. 11(3), pp. 163-171. 
Brilman, J. (2002) Nowoczesne koncepcje i metody zarządzania, Warszawa: PWE. Chor, D. (2010) 'Unpacking Sources of Comparative Advantage: A Quantitative Approach', Journal of International Economics, vol. 82, pp. 152-167.

Costinot, A., Donaldson, D. and Komunjer, I. (2012) 'What Goods Do Countries Trade? A Quantitative Exploration of Ricardo's Ideas', Review of Economic Studies, vol. 79, pp. 581-608.

Cohen, W.M., Nelson, R.R. and Walsh, J.P. (2002) 'Links and Impacts: The influence of Public Research on Industrial R\&D', Management Science, vol. 48(1), pp. 1-23.

Eaton, J. and Kortum, S. (2002) 'Technology, Geography, and Trade', Econometrica, vol. 70(5), pp. 1741-1779.

Everitt, B.S., Landau, S., Leese, M. and Stahl, D. (2011) Cluster Analysis, West Sussex, UK: John Willey \& Sons.

Foray, D., David, P.A. and Hall, B. (2009) Smart Specialisation - The Concept. Knowledge Economists Policy Brief, No. 9, pp. 1-5.

Golub, S. and Hsieh, Ch. (2000) 'Classical Ricardian Theory of Comparative Advantage Revisited', Review of Intenational Economics, vol. 8(2), pp. 221-234.

Gomułka, S. (1998) Teoria innowacji i wzrostu gospodarczego, Warszawa: CASE.

Griliches, Z. (1990) 'Patent Statistics as Economic Indicators: A Survey', Journal of Economic Literature, vol. 28, pp. 1661-1707.

Grossman, G.M. and Helpman, E. (1991) 'Innovation and Growth in the Global Economy', Cambridge: MIT Press.

Guellec, D. and van Pottelsberghe, B. (2007) 'The Economics of the European Patent System: IP Policy for Innovation and Competition', Oxford: Oxford University Press.

Guellec, D. and van Pottelsberghe, B. (2001) 'The internationalisation of technology analysed with patent data', Research Policy, vol. 30(8), pp. 1256-1266.

Guellec, D. and van Pottelsberghe, B. (2000) 'Applications, grants and the value of patents', Economics Letters, vol. 69 (1), pp. 109-114.

Hinze, S. and Schmoch, U. (2005) 'Opening the Black Box. Analytical approaches and their impact on the outcome of statistical patent analyses', in Glänzel, W., Moed, H. and Schmoch, U. (eds.), Handbook of Quantitative Science and Technology Research: The Use of Publication and Patent Statistics in Studies on R\&D Systems, Dordrecht/Boston/London: Kluwer Academic Publishers, pp. 215-235.

Jaffe, A.B. and Trajtenberg, M. (1996) 'Flows of Knowledge from Universities and Federal Labs: Modelling the Flow of Patent Citations Over Time and Across Institutional and Geographic Boundaries', Proceedings of the National Academy of Sciences, vol. 93, pp. 12671-12677.

Jaffe, A.B., Trajtenberg M. and Henderson, R. (1993) 'Geographic Localization of Knowledge Spillovers as Evidenced by Patent Citations', The Quarterly Journal of Economics, vol. 108, pp. 577-598. 
Kaufman, L. and Rousseeuw, P. (2005) Finding Groups in Data: An Introduction to Cluster Analysis, West Sussex, UK: John Willey \& Sons, pp. 12-21, 37-53.

Kerr, W.R. (2009) Heterogeneous Technology Diffusion and Ricardian Trade Patterns, Unpublished Manuscript, Harvard Business School.

Leromain, E. and Orefice, G. (2013) 'New revealed comparative advantage index: dataset and empirical distribution', CEPII Working Paper.

Levchenko, A. and Zhang, J. (2012) 'The evolution of comparative advantage: measurement and Welfare implications', Economic Policy, vol. 27(72), pp. 567-602.

Lucas, R.E. (1988) 'On the mechanics of economic development', Journal of Monetary Economics, vol. 22(1), pp. 3-42.

Lucas, R.E. (1990) 'Why Doesn't Capital Flow from Rich to Poor Countries?', American Economic Review, vol. 80, pp. 92-96.

Malerba, F. and Orsenigo, L. (1995) 'Schumpeterian Patterns of Innovation', Cambridge Journal of Economics, vol. 19(1), pp. 47-65.

Mankiw, N.G., Romer, D., and Weil, D.N. (1992) 'A Contribution to the Empirics of Economic Growth', The Quarterly Journal of Economics, vol. 107, pp. 407-437.

Nesta, L. and Patel, P. (2005) 'National patterns of technology accumulation: use of patent statistics', in Glänzel W., Moed, H. and Schmoch, U. (eds.), Handbook of Quantitative Science and Technology Research: The Use of Publication and Patent Statistics in Studies on R\&D Systems, Dordrecht/Boston/London: Kluwer Academic Publishers, pp. 531-551.

OECD, (2009) Patent Statistics Manual, Paris: OECD.

'Patents in the Knowledge-Based Economy' (2003), W.M. Cohen and S.A. Merrill, Washington The National Academies Press.

Pavitt, K., (1985) 'Patent statistics as indicators of innovative activities', Scientometrics, vol. 7, pp. 77-99.

Pavitt, K., (1988) 'International Patterns of Technological Accumulation', in Strategies in Global Competition, Hood N. and. Vahlne J.E (eds.), London: Croom Helm, pp. 126-157.

Posłuszny, K. (2011) 'Konkurencyjność międzynarodowa jako miara skuteczności restrukturyzacji przemysłu', Ekonomia Menedżerska, vol. 9, pp. 49-61.

Romer, P.M. (1990) 'Endogenous technological change', Journal of Political Economy, vol. 98(5), pp. S71-S102.

Romer, P.M. (1986) 'Increasing Returns and Long-Run Growth', Journal of Political Economy, 94(86).

Schmoch, U. (2008). Concept of a Technology Classification for Country Comparisons. Final Report to the World Intellectual Property Organisation, Karlsruhe: Fraunhofer Institute for Systems and Innovation Research.

Schumpeter, J. (1934) The Theory of Economic Development, Cambridge: Harvard University Press. 
Solow, R.M. (1967) Teoria kapitału i stopa przychodu, Warszawa: Państwowe Wydawnictwo Naukowe.

Stern, R.M. (1962) 'British and American Productivity and Comparative Costs in International Trade', Oxford Economic Papers, 14: 275-296.

Stern, S., Porter, M.E. and Furman, J.L. (2000) 'The Determinants of National Innovative Capacity', Working Paper, 7876, Cambridge: National Bureau of Economic Research.

Tokarski, T. (1998) 'Postęp techniczny a wzrost gospodarczy w modelach Solowa i Lucasa', Ekonomista, 2-3, pp. 271-291.

Tokarski, T. (1996) Postęp techniczny a wzrost gospodarczy w modelach endogenicznych, Ekonomista, 5.

\section{Appendix 1}

WIPO technology concordance table links for International Patent Classification (IPC).

\begin{tabular}{|c|l|l|}
\hline No. & \multicolumn{1}{|c|}{ Fields of technology } & \multicolumn{1}{c|}{ IPC codes } \\
\hline 1 & $\begin{array}{l}\text { Electrical machinery, ap- } \\
\text { paratus, energy }\end{array}$ & $\begin{array}{l}\text { F21H; F21K; F21L; F21S; F21V; F21W; F21Y; H01B; } \\
\text { H01C; H01F; H01G; H01H; H01J; H01K; H01M; } \\
\text { H02M; H02N; H02P; H05B; H05C; H05F; H99Z }\end{array}$ \\
\hline 2 & Audio-visual technology & $\begin{array}{l}\text { G09F; G09G; G11B; H04N3; H04N5; H04N7; } \\
\text { H04N9; H04N11; H04N13; H04N15; H04N17; } \\
\text { H04S; H05K }\end{array}$ \\
\hline 3 & Telecommunications & $\begin{array}{l}\text { G08C; H01P; H01Q; H04B; H04H; H04J; H04K; } \\
\text { H04M; H04N1; H04Q }\end{array}$ \\
\hline 4 & Digital communication & H04L; H04N21; H04W \\
\hline 5 & $\begin{array}{l}\text { Basic communication } \\
\text { processes }\end{array}$ & $\begin{array}{l}\text { H03B; H03C; H03D; H03F; H03G; H03H; H03J; } \\
\text { H03K; H03L; H03M }\end{array}$ \\
\hline 6 & Computer technology & $\begin{array}{l}\text { G06C; G06D; G06E; G06F; G06G; G06J; G06K; } \\
\text { G06M; G06N; G06T; G10L; G11C }\end{array}$ \\
\hline 7 & $\begin{array}{l}\text { IT methods for manage- } \\
\text { ment }\end{array}$ & G06Q \\
\hline 8 & Semiconductors & H01L \\
\hline 9 & Optics & $\begin{array}{l}\text { G02B; G02C; G02F; G03B; G03C; G03D; G03F; } \\
\text { G03G; G03H; H01S }\end{array}$ \\
\hline
\end{tabular}




\begin{tabular}{|c|c|c|}
\hline 10 & Measurement & $\begin{array}{l}\text { G01B; G01C; G01D; G01F; G01G; G01H; G01J; } \\
\text { G01K; G01L; G01M; G01N1; G01N3; G01N5; } \\
\text { G01N7; G01N9; G01N11; G01N13; G01N15; } \\
\text { G01N17; G01N19; G01N21; G01N22; G01N23; } \\
\text { G01N24; G01N25; G01N27; G01N29; G01N30; } \\
\text { G01N31; G01N35; G01N37; G01P; G01Q; G01R; } \\
\text { G01S; G01V; G01W; G04B; G04C; G04D; G04F; } \\
\text { G04G; G04R; G12B; G99Z }\end{array}$ \\
\hline 11 & $\begin{array}{l}\text { Analysis of biological } \\
\text { materials }\end{array}$ & G01N33 \\
\hline 12 & Control & $\begin{array}{l}\text { G05B; G05D; G05F; G07B; G07C; G07D; G07F; } \\
\text { G07G; G08B; G08G; G09B; G09C; G09D }\end{array}$ \\
\hline 13 & Medical technology & $\begin{array}{l}\text { A61B; A61C; A61D; A61F; A61G; A61H; A61J; A61L; } \\
\text { A61M; A61N; H05G }\end{array}$ \\
\hline 14 & Organic fine chemistry & $\begin{array}{l}\mathrm{A} 61 \mathrm{~K} 8 ; \mathrm{A61Q} ; \mathrm{C} 07 \mathrm{~B} ; \mathrm{C} 07 \mathrm{C} ; \mathrm{C} 07 \mathrm{D} ; \mathrm{C} 07 \mathrm{~F} ; \mathrm{C} 07 \mathrm{H} ; \\
\mathrm{C07J} ; \mathrm{C} 40 \mathrm{~B}\end{array}$ \\
\hline 15 & Biotechnology & $\begin{array}{l}\text { C07G; C07K; C12M; C12N; C12P; C12Q; C12R; } \\
\text { C12S }\end{array}$ \\
\hline 16 & Pharmaceuticals & $\begin{array}{l}\text { A61K6; A61K9; A61K31; A61K33; A61K35; A61K36; } \\
\text { A61K38; A61K39; A61K41; A61K45; A61K47; } \\
\text { A61K48 } \\
\text { A61K49; A61K50; A61K51; A61K101; A61K103; } \\
\text { A61K125; A61K127; A61K129; A61K131; A61K133; } \\
\text { A61K135; A61P }\end{array}$ \\
\hline 17 & $\begin{array}{l}\text { Macromolecular chemis- } \\
\text { try, polymers }\end{array}$ & C08B; C08C; C08F; C08G; C08H; C08K; C08L \\
\hline 18 & Food chemistry & $\begin{array}{l}\mathrm{A} 01 \mathrm{H} ; \mathrm{A} 21 \mathrm{D} ; \mathrm{A} 23 \mathrm{~B} ; \mathrm{A} 23 \mathrm{C} ; \mathrm{A} 23 \mathrm{D} ; \mathrm{A} 23 \mathrm{~F} ; \mathrm{A} 23 \mathrm{G} ; \\
\mathrm{A} 23 \mathrm{~J} ; \mathrm{A} 23 \mathrm{~K} ; \mathrm{A} 23 \mathrm{~L} ; \mathrm{C} 12 \mathrm{C} ; \mathrm{C} 12 \mathrm{~F} ; \mathrm{C} 12 \mathrm{G} ; \mathrm{C} 12 \mathrm{H} ; \mathrm{C} 12 \mathrm{~J} ; \\
\mathrm{C} 13 \mathrm{~B} 10 ; \mathrm{C} 13 \mathrm{~B} 20 ; \mathrm{C} 13 \mathrm{~B} 30 ; \mathrm{C} 13 \mathrm{~B} 35 ; \mathrm{C} 13 \mathrm{~B} 40 ; \\
\mathrm{C} 13 \mathrm{~B} 50 ; \mathrm{C} 13 \mathrm{~B} 99 ; \mathrm{C} 13 \mathrm{D} ; \mathrm{C} 13 \mathrm{~F} ; \mathrm{C} 13 \mathrm{~J} ; \mathrm{C} 13 \mathrm{~K}\end{array}$ \\
\hline 19 & Basic materials chemistry & $\begin{array}{l}\text { A01N; A01P; C05B; C05C; C05D; C05F; C05G; } \\
\text { C06B; C06C; C06D; C06F; C09B; C09C; C09D; } \\
\text { C09F; C09G; C09H; C09J; C09K; C10B; C10C; } \\
\text { C10F; C10G; C10H; C10J; C10K; C10L; C10M; } \\
\text { C10N; C11B; C11C; C11D; C99Z }\end{array}$ \\
\hline 20 & Materials, metallurgy & $\begin{array}{l}\mathrm{B} 22 \mathrm{C} ; \mathrm{B} 22 \mathrm{D} ; \mathrm{B} 22 \mathrm{~F} ; \mathrm{C} 01 \mathrm{~B} ; \mathrm{C} 01 \mathrm{C} ; \mathrm{C} 01 \mathrm{D} ; \mathrm{C} 01 \mathrm{~F} ; \\
\mathrm{C} 01 \mathrm{G} ; \mathrm{C} 03 \mathrm{C} ; \mathrm{C} 04 \mathrm{~B} ; \mathrm{C} 21 \mathrm{~B} ; \mathrm{C} 21 \mathrm{C} ; \mathrm{C} 21 \mathrm{D} ; \mathrm{C} 22 \mathrm{~B} ; \\
\mathrm{C} 22 \mathrm{C} ; \mathrm{C} 22 \mathrm{~F}\end{array}$ \\
\hline 21 & $\begin{array}{l}\text { Surface technology, coat- } \\
\text { ing }\end{array}$ & $\begin{array}{l}\mathrm{B} 05 \mathrm{C} ; \mathrm{B} 05 \mathrm{D} ; \mathrm{B} 32 \mathrm{~B} ; \mathrm{C} 23 \mathrm{C} ; \mathrm{C} 23 \mathrm{D} ; \mathrm{C} 23 \mathrm{~F} ; \mathrm{C} 23 \mathrm{G} ; \\
\mathrm{C} 25 \mathrm{~B} ; \mathrm{C} 25 \mathrm{C} ; \mathrm{C} 25 \mathrm{D} ; \mathrm{C} 25 \mathrm{~F} ; \mathrm{C} 30 \mathrm{~B}\end{array}$ \\
\hline
\end{tabular}




\begin{tabular}{|c|c|c|}
\hline No. & Fields of technology & IPC codes \\
\hline 22 & $\begin{array}{l}\text { Micro-structural and } \\
\text { nano-technology }\end{array}$ & B81B; B81C; B82B; B82Y \\
\hline 23 & Chemical engineering & $\begin{array}{l}\text { B01B; B01D1; B01D3; B01D5; B01D7; B01D8; } \\
\text { B01D9; B01D11; B01D12; B01D15; B01D17; } \\
\text { B01D19; B01D21; B01D24; B01D25; B01D27; } \\
\text { B01D29; B01D33; } \\
\text { B01D35; B01D36; B01D37; B01D39; B01D41; } \\
\text { B01D43; } \\
\text { B01D57; B01D59; B01D61; B01D63; B01D65; } \\
\text { B01D67; } \\
\text { B01D69; B01D71; B01F; B01J; B01L; B02C; B03B; } \\
\text { B03C; B03D; B04B; B04C; B05B; B06B; B07B; } \\
\text { B07C; B08B; C14C; D06B; D06C; D06L; F25J; } \\
\text { F26B; H05H }\end{array}$ \\
\hline 24 & $\begin{array}{l}\text { Environmental technol- } \\
\text { ogy }\end{array}$ & $\begin{array}{l}\text { A62C; B01D45; B01D46; B01D47; B01D49; } \\
\text { B01D50; B01D51; B01D52; B01D53; B09B; B09C; } \\
\text { B65F; C02F; } \\
\text { E01F8; F01N; F23G; F23J; G01T }\end{array}$ \\
\hline 25 & Handling & $\begin{array}{l}\text { B25J; B65B; B65C; B65D; B65G; B65H; B66B; } \\
\text { B66C; B66D; B66F; B67B; B67C; B67D }\end{array}$ \\
\hline 26 & Machine tools & $\begin{array}{l}\text { A62D; B21B; B21C; B21D; B21F; B21G; B21H; } \\
\text { B21J; B21K; B21L; B23B; B23C; B23D; B23F; } \\
\text { B23G; B23H; B23K; B23P; B23Q; B24B; B24C; } \\
\text { B24D; B25B; B25C; B25D; B25F; B25G; B25H; } \\
\text { B26B; B26D; B26F; B27B; B27C; B27D; B27F; } \\
\text { B27G; B27H; B27J; B27K; B27L; B27M; B27N }\end{array}$ \\
\hline 27 & Engines, pumps, turbines & $\begin{array}{l}\text { F01B; F01C; F01D; F01K; F01L; F01M; F01P; F02B; } \\
\text { F02C; F02D; F02F; F02G; F02K; F02M; F02N; F02P; } \\
\text { F03B; F03C; F03D; F03G; F03H; F04B; F04C; } \\
\text { F04D; } \\
\text { F04F; F23R; F99Z; G21B; G21C; G21D; G21F; } \\
\text { G21G; G21H; G21J; G21K }\end{array}$ \\
\hline 28 & $\begin{array}{l}\text { Textile and paper ma- } \\
\text { chines }\end{array}$ & $\begin{array}{l}\text { A41H; A43D; A46D; B31B; B31C; B31D; B31F; } \\
\text { B41B; B41C; B41D; B41F; B41G; B41J; B41K; } \\
\text { B41L; B41M; B41N; C14B; D01B; D01C; D01D; } \\
\text { D01F; D01G; D01H; D02G; D02H; D02J; D03C; } \\
\text { D03D; D03J; D04B; D04C; D04G; D04H; D05B; } \\
\text { D05C; D06G; D06H; D06J; D06M; D06P; D06Q; } \\
\text { D21B; D21C; D21D; D21F; D21G; D21H; D21J; } \\
\text { D99Z }\end{array}$ \\
\hline
\end{tabular}




\begin{tabular}{|c|c|c|}
\hline 29 & Other special machines & $\begin{array}{l}\text { A01B; A01C; A01D; A01F; A01G; A01J; A01K; A01L; } \\
\text { A01M; A21B; A21C; A22B; A22C; A23N; A23P; } \\
\text { B02B; B28B; B28C; B28D; B29B; B29C; B29D; } \\
\text { B29K; B29L; B99Z; C03B; C08J; C12L; C13B5; } \\
\text { C13B15; C13B25; C13B45; C13C; C13G; C13H; } \\
\text { F41A; F41B; F41C; F41F; F41G; F41H; F41J; } \\
\text { F42B; F42C; F42D }\end{array}$ \\
\hline 30 & $\begin{array}{l}\text { Thermal processes and } \\
\text { apparatus }\end{array}$ & $\begin{array}{l}\text { F22B; F22D; F22G; F23B; F23C; F23D; F23H; } \\
\text { F23K; } \\
\text { F23L; F23M; F23N; F23Q; F24B; F24C; F24D; } \\
\text { F24F; } \\
\text { F24H; F24J; F25B; F25C; F27B; F27D; F28B; F28C; } \\
\text { F28D; F28F; F28G }\end{array}$ \\
\hline 31 & Mechanical elements & $\begin{array}{l}\text { F15B; F15C; F15D; F16B; F16C; F16D; F16F; F16G; } \\
\text { F16H; F16J; F16K; F16L; F16M; F16N; F16P;;F16S; } \\
\text { F16T; F17B; F17C; F17D; G05G }\end{array}$ \\
\hline 32 & Transport & $\begin{array}{l}\text { B60B; B60C; B60D; B60F; B60G; B60H; B60J; } \\
\text { B60K; B60L; B60M; B60N; B60P; B60Q; B60R; } \\
\text { B60S; B60T; B60V; B60W; B61B; B61C; B61D; } \\
\text { B61F; B61G; B61H; B61J; B61K; B61L; B62B; } \\
\text { B62C; B62D; B62H; B62J; B62K; B62L; B62M; } \\
\text { B63B; B63C; B63G; B63H; B63J; B64B; B64C; } \\
\text { B64D; B64F; B64G }\end{array}$ \\
\hline 33 & Furniture, games & $\begin{array}{l}\text { A47B; A47C; A47D; A47F; A47G; A47H; A47J; A47K; } \\
\text { A47L; A63B; A63C; A63D; A63F; A63G; A63H; A63J; } \\
\text { A63K }\end{array}$ \\
\hline 34 & Other consumer goods & $\begin{array}{l}\text { A24B; A24C; A24D; A24F; A41B; A41C; A41D; } \\
\text { A41F; A41G; A42B; A42C; A43B; A43C; A44B; } \\
\text { A44C; A45B; A45C; A45D; A45F; A46B; A62B; } \\
\text { A99Z; B42B; B42C; B42D; B42F; B43K; B43L; } \\
\text { B43M; B44B; B44C; B44D; B44F; B68B; B68C; } \\
\text { B68F; B68G; D04D; D06F; D06N; D07B; F25D; } \\
\text { G10B; G10C; G10D; G10F; G10G; G10H }\end{array}$ \\
\hline 35 & Civil engineering & $\begin{array}{l}\text { E01B; E01C; E01D; E01F1; E01F3; E01F5; E01F7; } \\
\text { E01F9; E01F11; E01F13; E01F15; E01H; E02B; } \\
\text { E02C; } \\
\text { E02D; E02F; E03B; E03C; E03D; E03F; E04B; } \\
\text { E04C; E04D; E04F; E04G; E04H; E05B; E05C; } \\
\text { E05D; E05F; E05G; E06B; E06C; E21B; E21C; } \\
\text { E21D; E21F; E99Z }\end{array}$ \\
\hline
\end{tabular}

